NBER WORKING PAPER SERIES

\author{
WHY IS THERE CORPORATE \\ TAXATION IN A SMALL OPEN \\ ECONOMY? THE ROLE OF TRANSFER \\ PRICING AND INCOME SHIFTING
}

Roger H. Gordon

Jeffrey K. MacKie-Mason

Working Paper No. 4690

\author{
NATIONAL BUREAU OF ECONOMIC RESEARCH \\ 1050 Massachusetts Avenue \\ Cambridge, MA 02138 \\ March 1994
}

We would very much like to thank Scott Newlon for comments on an earlier draft, and Yong Yang for most able research assistance. The views expressed in this paper are those of the authors, and not necessarily those of the NBER. MacKie-Mason was a visitor at the Department of Economics, University of Oslo, while this paper was written. Financial support for this paper was in part provided through N.S.F. Grant No. SES 9122240. This paper is part of NBER's research program in Public Economics. 


\title{
WHY IS THERE CORPORATE \\ TAXATION IN A SMALL OPEN \\ ECONOMY? THE ROLE OF TRANSFER \\ PRICING AND INCOME SHIFTING
}

\begin{abstract}
Several recent papers argue that corporate income taxes should not be used by small, open economies. With capital mobility, the burden of the tax falls on fixed factors (e.g., labor), and the tax system is more efficient if labor is taxed directly. However, corporate taxes not only exist but rates are roughly comparable with the top personal tax rates. Past models also forecast that multinationals should not invest in countries with low corporate tax rates, since the surtax they owe when profits are repatriated puts them at a competitive disadvantage. Yet such foreign direct investment is substantial. We suggest that the resolution of these puzzles may be found in the role of income shifting, both domestic (between the personal and corporate tax bases) and cross-border (through transfer pricing). Countries need cash-flow corporate taxes as a backstop to labor taxes to discourage individuals from converting their labor income into otherwise untaxed corporate income. We explore how these taxes can best be modified to deal as well with cross-border shifting.
\end{abstract}

Roger H. Gordon

Department of Economics

University of Michigan

Ann Arbor, MI 48109

and NBER
Jeffrey K. MacKie-Mason

University Energy Center 2539 Channing Way

Berkeley, CA 94720

and NBER 


\section{Why is There Corporate Taxation in a Small Open Economy? The Role of Transfer Pricing and Income Shifting \\ Roger H. Gordon and Jeffrey K. MacKie-Mason}

The role of the corporate income tax in distorting capital investment and savings decisions has been investigated at length in the academic literature. ${ }^{1}$ While much progress has been made in understanding the behavioral implications of the tax, the recent literature has increasingly raised questions regarding why such taxes continue to exist. For example, Gordon (1986) and Razin and Sadka (1991) argued that a small open economy should not impose a source-based tax such as a corporate income tax on capital income. If capital is mobile and the country is a price-taker in the world capital market, then capital cannot bear the incidence of the tax. Firms would continue to locate in the country only if other factor prices (primarily for land and labor) drop by enough to compensate firms for the higher amount they have to generate pretax so as to be able to provide capital-owners the going rate of return after tax. But if these other factors bear the tax anyway, then it would be better to tax them directly, thereby eliminating a distortion that discourages capital investment in the country.

While the theory forecasts that small open economies should not impose source-based taxes on capital income, in fact essentially all developed economies do impose corporate income taxes. Not only are corporate tax rates nonzero, but in recent years they tend to be roughly comparable with the top personal tax rate in each country. Are countries systematically using a tax that is dominated by other available instruments? Or has something important been omitted from the existing theories? ${ }^{2}$

1 See Auerbach (1983), for example, for a recent survey of the effects of the tax on corporate investment.

2 A more extended discussion of alternative explanations for corporate taxation, and their limitations, can be found in Gordon (1992). 
The problem with the existing theories cannot be simply that they assume economies are small and open. If economies are large, then they certainly have an incentive to take advantage of their market power in world capital markets. Capital importers would want to reduce their capital imports to drive down the interest rate they pay on these imports, so would want to tax domestic investment and encourage domestic savings. Conversely, capital exporters would want to reduce their capital exports by taxing domestic savings and subsidizing domestic investment. But we do not see opposite patterns of taxation in capital-importing and capital-exporting countries, nor do we see sign changes when countries change from exporting to importing capital (as the U.S. did in the 1980's).

What if countries are not that open? Feldstein and Horioka (1980) provided striking empirical evidence suggesting that capital is quite immobile internationally. If economies are relatively closed, then it might appear that pressures due to capital mobility would be much abated, allowing capital income taxes to survive. But any conclusions here will depend critically on what factors limit capital mobility. Gordon and Bovenberg (1993) explore the policy implications of various possible explanations for the observed capital immobility, and find little prospect for rationalizing existing corporate taxes through this route.

The puzzles are not confined to government behavior. Firm behavior is also puzzling. Existing theories forecast, for example, that multinationals based in high-tax rate countries are at a distinct tax disadvantage when investing in low-tax-rate countries. As do all firms located there, they pay corporate income taxes to the local government. However, they pay additional taxes to their home government when profits are repatriated. This surtax should put the multinational at a tax disadvantage. Yet U.S. multinationals invest heavily even in the lowest-tax-rate countries; see, e.g., Hines and Rice (1990).

Reported rates of return also contradict the theoretical predictions. Domestic surtaxes on foreign earnings are postponed until repatriation, so multinationals face lower effective tax rates in countries with lower statutory rates. This implies that the pre-tax competitive rate of return should be lower in low-tax countries. But Hines and Hubbard (1990) and Grubert and Mutti (1987) find that pre-tax profit rates are higher in low-tax countries.

Observed investment and profit rates in low-tax countries are almost certainly explained 
by the ease with which a multinational can shift its accounting profits from high-tax to lowtax jurisdictions. For example, a subsidiary in a high-tax country can charge artificially low prices for outputs and pay artificially high prices for inputs that it exchanges with a subsidiary in a low-tax country. This lowers higher-taxed income and raises lower-taxed income, reducing the firm's global tax liabilities. Locating subsidiaries in tax havens facilitates this process, and it is not surprising that these subsidiaries as a result report a high pre-tax rate of return. Confirming evidence of the prevalence of income-shifting is provided by Harris et al. (1993). They find that firms with subsidiaries in low-tax countries pay lower U.S. taxes, and firms with subsidiaries in high-tax countries pay higher U.S. taxes, suggesting income shifting from high to low tax locations.

Cross-border income shifting alone cannot explain the puzzling aspects of government behavior, however. If we take account of not only the mobility of real capital but also the mobility of accounting profits, the pressures to reduce corporate tax rates are only increased. The forecast is still that corporate tax rates should equal zero.

Transfer pricing is not, however, the only important type of income shifting that is likely to occur. Musgrave (1959), for example, argued that a primary role for the corporate income tax is to close off opportunities for individuals to shift labor income to an otherwise untaxed corporate tax base. Without a corporate tax, for example, owner/managers of closely held firms could incorporate, retain earnings rather than pay them out as wages, then sell some of their shares, making their earnings subject to capital gains tax rates rather than labor income tax rates. A corporate tax would offset this tax incentive, and reduce the efficiency costs that such income shifting might induce.

In this paper, we model explicitly the effects of both forms of income shifting on behavior and on optimal tax policy. In section 1, we introduce only domestic income shifting (between personal and corporate income) and explore its effects on optimal tax design. We find that optimal source-based taxation on corporations is positive, with a tax rate equal to the labor income tax rate. The optimal tax is a pure profits or cash-flow tax.

In section 2, we add cross-border income shifting (transfer pricing) to the model. In response to transfer pricing, countries face incentives to tax elements of reported income that are most subject to transfer pricing at a reduced rate, or make them only partially 
deductible. The optimal corporate tax rate is now somewhat less than the rate on labor, which is consistent with most tax systems in developed countries (at least for the top tax rates on labor, which presumably apply to those people best able to shift income to the corporate sector).

We explore a variety of other seemingly puzzling aspects of existing corporate tax codes in section 3. Why, for example, do many countries allow multinationals to receive credits rather than deductions for taxes they paid abroad? Why are they taxed only when profits are repatriated? Why do host countries tax the income of foreign subsidiaries? We argue that these aspects of the law also make sense if the primary pressure affecting the design of the law is the need to prevent income shifting.

\section{Tax Policy With Domestic Income Shifting}

We first explore two approaches to modeling tax policy in the face of domestic income shifting. In the first, the model we will ultimately use for the host countries, individuals can shift the form of payment of their labor income from cash wages to nonwage forms, taxed in practice at the corporate tax rate. For example, a closely held firm in which the shares are owned by the manager and employees can retain what would otherwise have been wage payments, generating capital gains for the shareholder/employees. ${ }^{3}$ Eliminating wage deductions generates income subject to corporate taxes, while we assume for simplicity that the capital gains received by employees on their shares are free of personal taxes. Such income shifting presumably imposes real costs on the firm, however, since these alternative forms of compensation affect employees' liquidity and risk bearing, and may create complications due to asymmetric information about the value of these shares.

The second model, which we apply to home countries, assumes that only corporate entrepreneurs are in a position to shift their form of pay at a reasonable cost. When

\footnotetext{
3 Alternatively, the firm can pay employees in the form of stock transfers or qualified stock options rather than wages, generating extra taxable income for the firm due to the lost wage deductions and normally
generating only capital gains income for the employees.

4 In most countries personal capital income in at least some forms is taxed more lightly than labor income. Examples include a zero tax on capital gains that are passed to heirs at death; a lower tax rate on dividends; and favorable treatment of pension savings.
} 
individuals make a career choice between becoming an entrepreneur or an employec, and between incorporating or not, they take into account that income earned as an employce (or noncorporate entrepreneur) would be taxed under the personal income tax whereas income earned as a corporate entrepreneur could in practice be taxed under the corporate tax but exempt from personal taxes. The choices to become an entrepreneur and to incorporate both involve a variety of nontax considerations, however, that must be traded off with any tax factors.

In each model, a corporate income tax can be used to reduce the tax incentives that would otherwise exist to shift one's form of pay or one's career path. This role for the corporate income tax was mentioned at least as far back as Musgrave (1959). To focus on this role for the corporate tax, we will not introduce capital into the model. Our objective is not to rationalize the existence of capital income taxes, but of corporate income taxes. While existing corporate taxes do distort capital investment decisions, much of the revenue seems to be collected from the taxation of pure profits, which we interpret to represent the return to entrepreneurial ideas and effort. ${ }^{6}$ We are able to introduce a distortionary tax that captures the essential features of a corporate income tax without modeling capital explicitly.

\subsection{Optimal tax policy in home countries}

Consider first a situation in which corporate entrepreneurs but not other individuals can shift their income from the personal to the corporate tax base. In particular, assume that the population consists of a composite individual. This individual spends some fraction $1-h$ of his work effort as an employee, earning a wage $w$ that is taxed at the personal tax rate $t$. The remaining work effort is spent running corporations. Here, the net return per unit of effort before tax equals $\pi$; this income is taxable at rate $\tau$ leaving $\pi_{n} \equiv(1-\tau) \pi$

\footnotetext{
5 See Gravelle and Kotlikoff (1989), MacKie-Mason and Gordon (1993) and Gordon and Mackie-Mason (1994) for more detailed analyses of the decision whether to incorporate.

6 Gordon and Slemrod (1988) and Shoven (1991) have calculated that although the U.S. corporate income tax generates substantial revenues, capital income taxes in the U.S. in total have generated negative revenues in recent years.
} 
net of tax. ${ }^{7}$ Setting up a new corporation requires an outlay of resources, however, and we assume that there are diminishing returns to these expenditures. These start-up costs are assumed to be deductible against the profits tax. On net, we therefore describe the individual's net wage rate, $w_{n}$, by

$$
w_{n}=(1-h) w(1-t)+h(1-\tau) \pi-(1-\tau) c(h)
$$

where $c(h)$ measures the cost of setting up a new corporation of sufficient size to absorb the fraction $h$ of one's work time. The individual's resulting utility can be expressed by the indirect utility function $V\left(w_{n}\right)$.

Individuals decide how much to work, and how to split this time between being an employee vs. being an entrepreneur. The first-order condition for $h$ simply implies that $w(1-t)=(1-\tau)\left(\pi-c^{\prime}\right)$, so that the net returns from the two career paths are equalized at the margin, after taking into account the costs of becoming an entrepreneur.

Consider the optimal tax policy in this country. The government's objective is to choose the tax rates $t$ and $\tau$, so as to maximize the objective

$$
W=V\left(w_{n}\right)+\lambda L\{(1-h) t w+h \tau \pi-\tau c(h)\}
$$

where $L$ represents total hours of work, and where $\lambda$ measures the marginal utility received from extra government expenditures. Consider the effect of increasing $\tau$ and cutting $t$ simultaneously so as to leave $w_{n}$ unaffected. To keep $w_{n}$ unaffected, we need that $\partial t / \partial \tau=$ $-(h \pi-c(h)) /[(1-h) w]$. With $w_{n}$ fixed, $L$ also remains unchanged. Since $\partial W / \partial t=$ $\partial W / \partial \tau=0$ under the optimal policies, this combined tax change should leave welfare unaffected at the margin. The resulting first-order condition for this proposed tax change, after some simplification, equals

$$
\frac{\partial W}{\partial h}\left(\frac{\partial h}{\partial \tau}+\frac{\partial h}{\partial t} \frac{\partial t}{\partial \tau}\right)=0
$$

\footnotetext{
7 In general, $\tau$ includes both corporate and personal taxes due on corporate income. For simplicity of discussion, we will refer to $\tau$ as the corporate tax rate, as if no personal taxes are due on this income, whether it is paid out as dividends or realized as capital gains. Since the entrepreneur has the option to pay all income out as wages, the maximum effective tax rate on corporate income is $t$.
} 
Raising corporate taxes $(\tau)$ and lowering labor taxes $(t)$ lead to an unambiguous decrease in $h$, lowering the time spent as an entrepreneur and increasing time spent as an employee. Therefore, this first order condition implies that $\partial W / \partial h=0$, implying that $\tau\left(\pi-c^{\prime}\right)=t w$ under the optimal tax policy - the same taxes are paid regardless of carcer choice, so as not to distort the individual's choice of $h$. Substituting for $\pi-c^{\prime}$ from the individual's first-order condition, we find that $\tau=t$ under the optimal policy.

In addition, we can show that the government would not want to introduce a distorting tax on corporate activity. Consider, for example, some distorting $\operatorname{tax} \sigma$ on the firm, leaving it with net profits $(1-\tau)[\pi-S(\sigma, X)]$, where $X$ represents the real decisions made by the firm which are distorted by $\sigma$. The government's policy objective would now equal

$$
W=V\left(w_{n}\right)+\lambda L\{(1-h) t w+h(\tau \pi+(1-\tau) S)-\tau c(h)\}
$$

In order to show that the optimal value of $\sigma$ is zero, consider the effects of raising $\sigma$ and simultaneously lowering $\tau$ so as to leave $w_{n}$ and thus $L$ unchanged. This requires that $\partial \tau / \partial \sigma=-[(1-\tau) h /(h(\pi-S)-c)] \partial S / \partial \sigma$. The resulting first-order condition for $W$ is $^{8}$

$$
\frac{\partial W}{\partial h}\left(\frac{\partial h}{\partial \sigma}+\frac{\partial h}{\partial \tau} \frac{\partial \tau}{\partial \sigma}\right)+\lambda L h\left(\tau \frac{\partial \pi}{\partial X}+(1-\tau) \frac{\partial S}{\partial X}\right) \frac{\partial X}{\partial \sigma} .
$$

By equation (1), $\partial W / \partial h=0$ under the optimal tax policy, so that the first term in equation (2) is zero. Since the firm's first-order condition for $X$ implies that $\partial \pi / \partial X=\partial S / \partial X$, equation (2) implies that $\partial S / \partial X=0$ under the optimal policy. Since by assumption $\sigma$ distorts the firm's choice of $X, \partial S / \partial X$ can equal zero only when $\sigma=0$. The optimal tax policy therefore consists of a wage tax plus a non-distortionary cash-flow corporate tax at equal rates.

\subsection{Optimal tax policy in host countries}

Consider next a slightly different model, in which all employees are in a position to shift the tax treatment of their labor income. In particular, assume that there is only one source of employment, working to produce some good $X$. This good is produced using a constant

\footnotetext{
8 Since a pure profits tax rate is non-distorting, changing $\tau$ cannot change the firm's choice of $X$.
} 
returns technology subject to free entry, so that there are no pure profits in equilibrium. Normally, we would assume that all earnings are paid out as wages, taxed at the personal rate $t^{*}$. Now add the complication that if the tax rate on a firm's income, denoted by $\tau^{*}$, is lower than that on labor income, then the firm can pay individuals in a form that is taxed at the firm's rate rather than at the individual's rate. This income shifting is not costless, however. If the individual receives the fraction $s$ of her labor income $w^{*}$ in a form taxable at the firm's tax rate, we assume that the labor costs to the firm equal $w^{*}(1+b(s))$. Here, $b(s)$ represents the real costs of shifting the tax treatment of labor income, where by assumption $b(s)$ is convex, $b^{\prime}>0$, and $b(0)=0$. In equilibrium, firms continue to break even, so that $p=w^{*}(1+b)$.

The net wage rate, $w_{n}^{*}$, of the representative individual therefore equals

$$
w_{n}^{*}=w^{*}\left[(1-s)\left(1-t^{*}\right)+s\left(1-\tau^{*}\right)\right]
$$

The individual chooses $s$ so as to maximize her after-tax wage, holding fixed the wage costs of the firms, giving as a first-order condition for $s$ :

$$
\frac{b^{\prime}}{1+b}=\frac{t^{*}-\tau^{*}}{\left(1-t^{*}\right)+s\left(t^{*}-\tau^{*}\right)}
$$

It is straightforward to show that $s$ is increasing in $t^{*}-\tau^{*}$. This individual's utility equals $V^{*}\left(w_{n}^{*}\right)$. Denote the individual's labor supply by $L^{*}$.

Consider next the optimal policy of a host-country government. The objective function of this government is

$$
W^{*}=V^{*}\left(w_{n}^{*}\right)+\lambda^{*} L^{*}\left[\tau^{*} p-\tau^{*} w^{*}(1+b(s))+t^{*} w^{*}(1-s)+\tau^{*} s w^{*}\right]
$$

where again $\lambda^{*}$ represents the marginal utility received from extra government expenditures. What happens if the government raises $\tau^{*}$ and simultaneously lowers $t^{*}$ by an amount chosen so as to leave $w_{n}^{*}$ and therefore $L^{*}$ unchanged? Note that, given the lack of pure profits, changes in $\tau^{*}$ leave firms unaffected as well. However, these changes make income shifting less attractive, so $s$ falls, causing $w^{*}$ to rise. The resulting change in social welfare equals

$$
\left[\frac{\tau^{*}-t^{*}}{\left(1-t^{*}\right)+s\left(t^{*}-\tau^{*}\right)}\right]\left(\frac{\partial s}{\partial \tau^{*}}+\frac{\partial t^{*}}{\partial \tau^{*}} \frac{\partial s}{\partial t^{*}}\right)=0
$$


Given that this policy change leads to a drop in income shifting, the term in brackets should equal zero, implying that $\tau^{*}=t^{*}$. Again, the optimal tax system consists of a wage tax plus a cash-flow corporate tax at equal rates.

An alternative to this wage tax, combined with a cash-flow tax on firms to prevent income shifting, would have been simply to tax output of firms at some rate $\sigma^{*}$. Given our assumptions, raising $\sigma^{*}$ is equivalent to raising $\tau^{*}$ and $t^{*}$ simultaneously-both simply tax labor income and distort only the labor supply decision. This is simply the equivalence of a uniform value-added tax and a labor income tax.

\section{Tax Policy With Cross-Border Income Shifting}

With domestic income shifting alone, we find that countries face an incentive to supplement a labor income tax with a cash-flow tax on corporate income at the same rate. How does this optimal tax structure change if we now take into account that each economy is open, that multinationals can set up subsidiaries abroad, and that transfer pricing allows these firms to shift accounting income easily between the parent firm and the subsidiary? Many types of situations could be examined. We focus on the effects of possible transfer pricing between the parent firm and its subsidiaries, and ignore other forms of mobility across borders.

To capture these ideas formally, we develop a model with two types of countries, home countries and host countries. We allow for multiple countries of each type, and assume that each is a price taker in international markets. We will examine policies for some representative home country $j$ or representative host country $i$.

Multinationals are based in countries of type $j$, and use an imported good $X$ to produce a good $Q$. If the representative individual in a country $j$ allocates time $h$ to producing $Q$, we assume that the resulting output equals $h f(X)-c(h)$, produced using inputs $h X$, where $f(0)=0, f^{\prime}>0$ and $f^{\prime \prime}<0 .^{9}$ The firm takes as given the price for $Q$ in the output market, and this price is the numeraire. The input $X$ can be purchased on the international market at price $p$, or alternatively the firm can acquire a subsidiary in sorne

\footnotetext{
9 The rest of his time is still spent as an employee earning a wage $w$ taxable at rate $t$.
} 
country $i$, produce $X$ there, then sell this good to the parent firm for some accounting price $p^{*}$. We assume that the same accounting price, $p^{*}$, must be used for tax purposes in the host country.

In any country $i, X$ can be produced by either domestic firms or foreign subsidiaries. Labor is the only input used to produce $X$, and the production function is simply $X=L^{*}$. For simplicity, we assume that multinationals have no technological advantage in producing $X$ - the only reason for a multinational to open up a foreign subsidiary is to take advantage of transfer pricing. The going net-of-tax wage rate is $w_{n}^{*}$. As described above, the firm can either pay workers cash wages or at a cost pay them in a form taxed at the corporate rate rather than the personal rate. If the fraction $s$ of labor income is paid in a form taxed at the corporate rate, then the pretax wage rate faced by the firm equals $w^{*}(1+b(s))$, where $w^{*}$ adjusts so as to leave workers with the going net-of-tax wage, $w_{n}^{*}$.

Each country is assumed to tax pure profits, with a rate $\tau$ in country $j$ and a rate $\tau^{*}$ in country $i$. In addition, we assume that country $j$ (country $i$ ) imposes a surtax on sales revenue at rate $\sigma\left(\sigma^{*}\right)$. Surtax payments are assumed to be deductible under the pure profits part of the tax. For example, a firm in country $j$ buying inputs on the open market would pay in taxes $[\tau(1-\sigma)+\sigma] f(X)-\tau p X .^{10} 11$

For convenience of notation, we let $T=\tau(1-\sigma)+\sigma$ represent the effective tax rate on gross sales revenue for operations in country $j$, so that a firm in country $j$ pays $T f(X)-\tau p X$ in taxes. We define $T^{*}$ analogously.

Consider the incentive faced by firms in country $j$ to acquire subsidiaries in country $i$. If a multinational acquires a subsidiary in country $i$, then it must pay taxes to the host country on its operations there, and it may also owe some surtax to home country $j$ on the income generated in $i .^{12}$ Denote the resulting effective gross tax rate on subsidiary

10 We capture the difference in existing corporate taxes from a pure profits tax by this surtax on output. For example, if $X$ represents capital equipment, then this rate difference can capture the fact that revenues are taxable immediately, whereas the amount spent buying capital is deductible only gradually over time. If instead $X$ represents materials, then inventory accounting rules can also lead to a postponed deduction.

11 In country $j$, the entrepreneur's startup costs are also deductible at the corporate tax rate, so total corporate taxes are reduced by $r c(h)$. However, this deduction affects only the individual's time allocation, not the firm's optimal choices of $p^{*}$ and $X$, and so we suppress this tax term when studying firm behavior.

Many countries including the U.S. tax foreign-source income when it is repatriated, with a credit given 
revenues by $T_{r}$. Due to the horne country surtax, $T_{r} \geq T^{*}$, but because the tax is deferred until the income is repatriated, $T_{r} \leq T .^{13}$ Similarly, denote the effective tax rate on subsidiary wage deductions by $\tau_{r}$, where $\tau^{*} \leq \tau_{r} \leq \tau$. Given $T_{r}$ and $\tau_{r}$, we define $\sigma_{r}$ implicitly by the relation $\left(1-\tau_{r}\right)\left(1-\sigma_{r}\right)=\left(1-T_{r}\right)$. In order to parameterize the degree to which surtaxes are due on foreign-source income, we assume that $T_{r}=\rho T+(1-\rho) T^{*}$ and that $\tau_{r}=\rho \tau+(1-\rho) \tau^{*}$ for some $\rho$, where $0 \leq \rho \leq 1 .^{14}$

We focus on tax systems that give multinationals an incentive to shift profits out of the home country. With a subsidiary that provides an input, profits can be shifted by paying a higher price for the input. The increased factor cost in the home country is deducted at rate $\tau$, while the increased revenue for the subsidiary is taxed at an effective rate of $T_{r}$. Therefore, to make transfer pricing attractive, we assume for purposes of discussion that $\tau>T_{r}$.

If the firm can set its own factor transfer price by choosing some arbitrary accounting price $p^{*}$ for the input $X$, and if $\tau>T_{\mathrm{r}}$, then we would forecast without other additions to the model that all taxable profits would be shifted to the subsidiary. That rarely seems to be the case. ${ }^{15}$ To rationalize this, we assume that the tax authorities expend resources trying to prevent use of transfer pricing, and the threat of being caught and fined limits a firm's use of transfer pricing. ${ }^{16}$

for foreign taxes paid on this income. Firms may or may not have sufficient foreign tax credits to eliminate all home country tax on the subsidiary's income.

13 Deferral is a gain only to the extent to which funds kept abroad can be invested there earning a higher after-local-tax rate of return than the individual's after-home-tax discount rate. If there were no taxation of capital income and full capital mobility, then $T_{r}=T$ in spite of deferral.

14 If the firm repatriates profits every year, and does not have excess credits, then $\rho=1$; if the firm systematically has excess credits, then $\rho=0$. In general, the value of $\rho$ depends on the length of time repatriation is deferred, the gain from deferral given the rate of return abroad relative to the discount rate, and the likelihood that the firm has excess credits. It is worth noting that $\sigma_{r}$, which is defined implicitly by $\left(1-\sigma_{r}\right)=\left(1-T_{r}\right) /\left(1-\tau_{r}\right)$, does not satisfy $\sigma_{r}=\rho \sigma+(1-\rho) \sigma^{*}$.

15 US firms taking advantage of the "possessions tax credit" by manufacturing in Puerto Rico apparently come close to total income shifting; see Grubert and Slemrod (1993).

16 In an earlier version of this paper we also constructed a model in which the accounting price, $p^{*}$, is used by the parent firm's manager in deciding how much $X$ to purchase, creating an inelficiency since the transfer price is artificially high. Such inefficiencies might arise within a firm due to principal-agent problems, or due to the high transactions costs of keeping one set of books for tax reporting and another set for management operations. (Transfer price accounting is at a much finer level of detail and complexity 
In particular, in order to limit use of transfer pricing, the government is assumed to expend resources trying to detect use of transfer pricing. Due to these enforcement efforts, the government would have some probability $\theta$ of documenting the use of transfer prices, where $\theta$ should be an increasing function of $p^{*}$. If the firm is caught using transfer prices, then it would need to pay in additional taxes an amount $\tau\left(p^{*}-p\right) F X$ on domestic earnings, where $F$ reflects any fines that are imposed (and perhaps any systematic deviation of the corrected price from $p$ ). If the corrected price is then used in assessing the tax at repatriation on foreign-source income, then the firm also receives back an amount $\rho T\left(p^{*}-\right.$ p) $F X$ on the taxes paid on repatriated foreign earnings if caught using transfer pricing, ${ }^{17}$ implying an expected net penalty of $(\tau-\rho T)\left(p^{*}-p\right) F X \theta$. We explore the concrete example where $\theta=a\left[\left(p^{*}-p\right) / p\right]^{\beta}$, with $\beta>0$, and for simplicity assume risk neutrality.

\subsection{Behavior of Multinationals With Cross-Border Shifting}

For any given $h$, a multinational chooses $X$ and $p^{*}$ to maximize its net profits of

$$
\pi_{n}=(1-T) f(X)-(1-\tau) p^{*} X+\left(1-T_{r}\right) p^{*} X-\left(1-\tau_{r}\right) w^{*}(1+b) X-(\tau-\rho T)\left(p^{*}-p\right) F X \theta
$$

Given this objective function, the first-order condition for $p^{*}$ can easily be solved to show that

$$
p^{*}=p\left[1+\left(\frac{\tau-T_{r}}{(\beta+1) a F(\tau-\rho T)}\right)^{1 / \beta}\right] .
$$

The optimal value of $p^{*}$ is decreasing in the severity of enforcement, as measured here by $a F .^{18}$ In addition, $p^{*}$ is increasing in $\tau$, but decreasing in $T^{*}$ and $T$. Increasing $\tau$ raises the value of deducting a high imput cost, $p^{*}$. Increasing $T^{*}$ or $T$ (and thus $T_{r}$ ) reduces the value of reporting a high foreign unit revenue, $p^{*}$. Also, $p^{*}>p$ as long as $\tau>T_{r}$.

than the separate tax and financial reporting income statements and balance sheets that firms in many countries are required to maintain.) The results of this model were qualitatively similar to the results we present so we do not report the details here.

17

We assume here that the fine is assessed on the net change in overall tax liability, and that foreign tax payments are unaffected by these recalculations of domestic tax liabilities.

18

In general, the direction of effect of $\beta$ on $p^{*}$ is ambiguous. 
It will prove convenient to note that at this optimal value of $p^{*}$, the value of $F \theta$ equals ${ }^{19}$

$$
F \theta=\frac{\tau-T_{r}}{(\beta+1)(\tau-\rho T)}
$$

If we substitute this expression for $F \theta$ into the profit measure, we find that net profits equal $^{20}$

$$
\pi_{n}=(1-T) f(X)-(1-\tau) p X+\frac{\beta}{\beta+1}\left(\tau-T_{r}\right)\left(p^{*}-p\right) X-\rho\left(1-\tau_{r}\right)\left(\sigma-\sigma^{*}\right) p X
$$

Here, the first two terms measure what profits would have been, had the firm simply purchased $X$ on the open market. The third term measures the net gain from use of transfer pricing, after taking into account the effects of tax enforcement - tax enforcement not only lowers $p^{*}$ but also recaptures the fraction $1 /(1+\beta)$ of the tax savings from transfer pricing. This term in itself raises profits. The last term reflects the fact that, without use of transfer pricing, the subsidiary operates at a competitive disadvantage because of the surtaxes due when profits are repatriated.

The first-order condition for $X$ can be written, after substituting for the value of $F \theta$, as

$$
(1-T) f^{\prime}=(1-\tau) p-\frac{\beta}{\beta+1}\left(\tau-T_{\mathbf{r}}\right)\left(p^{*}-p\right)+\rho\left(1-\tau_{\mathbf{r}}\right)\left(\sigma-\sigma^{*}\right) p
$$

Here, the left-hand side equals the value of the extra output whereas the right-hand side equals the net-of-tax cost of the extra input. Only the first term on the right-hand side appears if the firm does not set up a subsidiary. Since the second term on the right-hand side is negative whereas the third term is positive, it would appear that the change in $X$ due to use of transfer pricing is ambiguous. However, we show next that $X$ must increase whenever the subsidiary is worth acquiring.

When is the subsidiary worth acquiring? The answer depends on the extent of enforcement in the home country. Comparing profits with or without the subsidiary, and

19 Note that the equilibrium probability of being caught is independent of $a$ and a decreasing function of $\beta$

20 In simplifying this expression, we have assumed that competitive firms survive in the host country, so that $\left(1-\sigma^{*}\right) p=w^{*}(1+b)$. 
simplifying using a second-order approximation to output around the output level without the subsidiary, the change in profits from opening the subsidiary equals

$$
\Delta \pi_{n} \approx .5(1-T) f^{\prime \prime}\left(X_{s}-X\right)^{2}+X_{s}\left[\frac{\beta}{\beta+1}\left(\tau-T_{r}\right)\left(p^{*}-p\right)-\rho\left(1-\tau_{r}\right)\left(\sigma-\sigma^{*}\right) p\right],
$$

where $X$, is the chosen output level with the subsidiary, and $X$ is the chosen output level without it. For the subsidiary to be worth opening, the sum of the terms inside the brackets must be positive, since the first term is necessarily negative. Equation (5) then implies that $X,>X$. Therefore, a necessary but not sufficient condition for the subsidiary to be worth opening is that desired output increase with the subsidiary. As tax enforcement (measured by $a F$ ) increases, the first term inside the brackets becomes smaller, due to the fall in $p^{*}$, and is eventually dominated by the second term. ${ }^{21}$ Therefore, subsidiaries and transfer pricing would no longer be attractive if there is sufficient tax enforcement. Similarly, as $\rho$ rises, increasing the importance of the surtax at repatriation, then $T_{r}$ increases and $p^{*}$ falls. Both these changes cause the first term inside the brackets to fall. In addition, the rise in $\rho$ causes the second term to become more negative, again making the subsidiary less attractive.

If $X$ is produced in various countries, each with its own tax structure, where will the multinational prefer to invest? Assume that $w^{*}$ has been set so that competitive firms break even in all countries where $X$ is produced, implying that $p\left(1-\sigma^{*}\right)=w^{*}(1+b)$. To judge the locational preferences of a multinational we examine how the firm's aggregate profits, as measured in equation (4), change as we vary the tax rates faced in country $i$. The derivative of the firm's profits with respect to $\tau^{*}$, taking into account the forecast that wages will not vary, equals $-(1-\rho) X\left[\left(1-\sigma^{*}\right) p^{*}-w^{*}(1+b)\right]$. Since this expression equals zero when $p^{*}=p$, it is necessarily negative given that $p^{*}>p$, yielding the expected conclusion that multinationals prefer to invest in countries with lower $\tau^{*} .{ }^{22}$ Put differently, they would be willing to pay somewhat higher wage rates in countries with lower $\tau^{*}$, potentially leading to production where real resource costs are not minimized.

\footnotetext{
21 In general, however, increasing $\beta$ has ambiguous effects on the net gain from transfer pricing.

22 As expected, introducing transfer pricing enables us to rationalize the substantial activity by multinationals in tax havens.
} 
Similarly, if we differentiate equation (4) with respect to $\sigma^{*}$, taking into account the forecasted change in $w^{*}$, we get

$$
X\left[\left(1-\tau_{r}\right) p-(1-\rho)\left(1-\tau^{*}\right) p^{*}\right]
$$

The first term in this equation reflects the fact that countries with a higher $\sigma^{*}$ have lower wage rates, making them more attractive locations, everything else equal. However, the higher $\sigma^{*}$ also means higher local tax payments, which are only partly offset by the credit received against home country taxes when profits are repatriated. If repatriation of profits can be deferred for a long time, so that $\rho \approx 0$, then the second term dominates and the firm would prefer to invest in countries with a low value of $\sigma^{*}$. But this is not generally true.

\subsection{Optimal tax policy in the host country}

Consider next the optimal tax policy in the host country, now allowing for the possible setup of subsidiaries and the resulting use of transfer pricing. The objective of the government now equals

$$
W^{*}=V\left(w_{n}^{*}\right)+\lambda^{*} L^{*}\left[T^{*} p^{*}-\tau^{*} w^{*}(1+b(s))+t^{*} w^{*}(1-s)+\tau^{*} s w^{*}\right]
$$

In analyzing this case, we assume that multinationals own all production facilities, and that the wage is set so that they are indifferent to locating in this country rather than in some other country. If the country is small, then at the margin the domestic wage must adjust in response to any given tax change so as to leave net profits of multinationals unaffected. (If the wage falls far enough, domestic ownership will replace foreign ownership.)

Consider then what happens if the government raises $\sigma^{*}$ while simultaneously lowering $\tau^{*}$ so as to leave profits of multinationals unaffected at the existing wage rate. Under these simultaneous tax changes, $T^{*}$ falls to compensate for the fall in the rate that applies to tax deductions, leading to a rise in $p^{*}$. In addition, assume that the government simultaneously raises $t^{*}$ to compensate for the fall in $\tau^{*}$ so as to leave $w_{n}^{*}$ and therefore $L^{*}$ unaffected. These tax changes cause $s$ to rise, leading to a compensating fall in $w^{*}$ so as to leave 
$w^{*}(1+b)$ unchanged. The resulting change in social welfare must equal zero, implying that

$$
T^{*}\left(\frac{\partial p^{*}}{\partial \sigma^{*}}+\frac{\partial p^{*}}{\partial \tau^{*}} \frac{\partial \tau^{*}}{\partial \sigma^{*}}\right)=\frac{w^{*}\left(t^{*}-\tau^{*}\right)}{\left(1-t^{*}\right)+s\left(t^{*}-\tau^{*}\right)}\left(\frac{\partial s}{\partial t^{*}} \frac{\partial t^{*}}{\partial \sigma^{*}}+\frac{\partial s}{\partial \tau^{*}} \frac{\partial \tau^{*}}{\partial \sigma^{*}}\right) .
$$

We conclude from equation (8) that $\operatorname{sign}\left(T^{*}\right)=\operatorname{sign}\left(t^{*}-\tau^{*}\right)$. Given the need for government revenue, the sign of each must be positive, implying that $T^{*}>0$ and $t^{*}>\tau^{*}$. Not only is there a positive corporate tax, but in general this tax will be distorting-there is nothing in equation (8) causing $T^{*}$ to equal $\tau^{*}$.

Simply taxing labor income directly leads to efficiency losses due to income shifting, whereas the alternative of taxing output creates an efficiency loss by making the country a less attractive location for multinationals. These two sources of efficiency loss are traded off under the optimal tax system.

Note that if domestic income shifting is not a problem so that $s$ is not responsive to tax policy, then the right-hand side of equation (8) equals zero. We then infer that $T^{*}=0$ under the optimal policy, making the country a very attractive location for multinationals, in effect a tax haven. Given the lack of domestic income shifting, taxes are simply collected on labor income. If all labor income is paid out as wages, this can be done either through a personal tax on labor income, a payroll tax at the firm level, or a refundable V.A.T. ${ }^{23}$

If, instead, domestic income shifting is responsive enough to tax policy, so that the optimal value of $T^{*}$ is high, then multinationals would be outbid for workers by domestic firms. But with only domestic operations surviving, output prices would no longer be responsive to tax policy, implying as in the original model that the tax system simply consists of a tax on labor income, taking the form either of a personal wage tax supplemented by a cash-flow corporate tax at an equal rate, or instead a value-added tax.

In general, there are two local optimum for tax policy. One has a low $T^{*}$ satisfying equation (8), leading foreign multinationals to set up local subsidiaries. The second has a high $T^{*}$, no activity by multinationals, but no domestic income shifting. Which local optima dominates would depend on the country's circumstances. In choosing between

23 Note that if the V.A.T. is not refundable, and adjustment occurs instead through changes in the exchange rate, then the tax still distorts the transfer pricing decisions of foreign subsidiaries. 
the two local optima, a country would make a conscious decision whether or not to be a tax haven and thereby attract foreign multinationals at the expense of undermining its domestic tax system.

One other result worth noting is that the host country docs not attempt to take advantage of the credits offered to multinationals when they repatriate profits - as seen in equation (8), the size of any credit, which is captured by $\rho$, does not affect the host country's optimal tax policy. This result holds as long as $\rho<1$, and stands in contrast to the results in Gordon (1992), derived assuming $\rho=1$. Even though the net cost of a host country tax may be small to a multinational, competition among host countries drives this tax to zero.

\subsection{Optimal tax policy in the home country}

What can be said about optimal tax policy in the home country, once we take into account the ability of multinationals to shift their profits abroad? The government's objective function now becomes

$$
\begin{gathered}
W=V\left(w_{n}\right)+\lambda L\{(1-h) t w-e(a)-\tau c(h)+ \\
\left.h\left[T f(X)-\tau p^{*} X+\rho\left(T-T^{*}\right) p^{*} X-\rho\left(\tau-\tau^{*}\right) w^{*}(1+b) X+(\tau-\rho T)\left(p^{*}-p\right) X F \theta\right]\right\} .
\end{gathered}
$$

Here, $e(a)$ measures the real costs of monitoring the use of transfer pricing at an intensity level $a$.

We first consider the optimal revenue surtax, $\sigma$. We showed above that with no crossborder shifting $\sigma=0$, and the optimal corporate tax was a non-distortionary cash flow tax. That result no longer holds when firms can use transfer pricing to shift income across borders.

In the appendix we show that $\partial W / \partial X>0$ when tax rates are optimized. To use this result, first differentiate $W$ with respect to $X$ to find that

$$
T f^{\prime}-\tau p^{*}+\rho\left(T-T^{*}\right) p^{*}-\rho\left(\tau-\tau^{*}\right) w^{*}(1+b)+(\tau-\rho T)\left(p^{*}-p\right) F \theta>0 .
$$

We can rewrite equation (5), the first-order condition for $X$, as

$$
(1-T) f^{\prime}-(1-\tau) p+\left(\tau-T^{*}\right)\left(p^{*}-p\right)-\rho\left(T-T^{*}\right) p^{*}+\rho\left(\tau-\tau^{*}\right) w^{*}-(\tau-\rho T)\left(p^{*}-p\right) F \theta=0 .
$$


Since we have shown that $(1-T) f^{\prime}<(1-\tau) p$ (i.e., $X$ is greater with a subsidiary than without), the sum of the last four terms of (11) must be positive when opening a subsidiary is profitable. Multiplying equation (11) by $\tau /(1-\tau)$ and subtracting from equation (10) yields

$$
\begin{aligned}
& \sigma f^{\prime}-T^{*}\left(p^{*}-p\right)- \\
& \frac{1}{1-\tau}\left[\left(\tau-T^{*}\right)\left(p^{*}-p\right)-\rho\left(T-T^{*}\right) p^{*}+\rho\left(\tau-\tau^{*}\right) w^{*}-(\tau-\rho T)\left(p^{*}-p\right) F \theta\right]>0
\end{aligned}
$$

We showed in (11) that the sum of the terms in the brackets is positive. Therefore, $\sigma>0$ under the optimal policy, which means that a distortionary corporate tax is used. Taxing entrepreneurs using $\tau$ is now more costly because it induces transfer pricing. As a result, entrepreneurs are taxed instead at least in part by a distorting tax, $\sigma$, on gross revenue. This tax also prevents an excessive shift into entrepreneurial activity and lessens the firm's use of transfer pricing, but at the cost of distorting the firm's internal decisions.

We now characterize the relationship between the optimal $t, \tau$, and $T$. To do so, we make use of another result proved in the appendix: that $\partial W / \partial h<0$ (holding $w_{n}$ constant) when policies are at their optimal values. Since, by utility maximization, $\partial w_{n} / \partial h=0$, this result implies that at the optimal policy tax revenue - the other component of social welfare- falls at the margin as $h$ increases. As a result, the labor income tax must exceed the effective tax rate on time spent as an entrepreneur, another distortion not present without transfer pricing. The opportunity for transfer pricing makes it more difficult to tax entrepreneurial activity. Under optimal policy, there is a trade off between cutting the distortion favoring entrepreneurial activity and increasing the distortion encouraging transfer pricing.

To show this more formally, take the derivative of $W$ with respect to $h$, holding $w_{n}$ constant, to get

$$
T f-X\left[\tau p^{*}-\rho\left(T-T^{*}\right) p^{*}+\rho\left(\tau-\tau^{*}\right) w^{*}(1+b)-(\tau-\rho T)\left(p^{*}-p\right) F \theta\right]-t w-\tau c^{\prime}<0
$$

Multiplying (10), $\partial W / \partial X$, by $X$ and subtracting from (13) yields

$$
T\left(f-X f^{\prime}\right)-t w-\tau c^{\prime}<0
$$


Multiply the individual's first-order condition for $h$ by $\tau /(1-\tau)$ and subtract, to find that

$$
T\left(f-f^{\prime} X\right)-\frac{(t-\tau)}{1-\tau} w-\frac{\tau}{1-\tau} \pi_{n}<0 .
$$

Now multiply the firm's first-order condition for $X$ by $X$ and rearrange to find

$$
\frac{\pi_{n}}{1-\tau}=(1-\sigma)\left(f-f^{\prime} X\right)
$$

Substituting and rearranging terms yields

$$
\sigma\left(f-f^{\prime} X\right)-\frac{(t-\tau)}{1-\tau} w<0
$$

Since the concavity of $f(X)$ ensures that the first term is positive, we learn that $t>\tau$ under the optimal policy.

Finally, we can also show that $T<t$ under the optimal policy. To see this, first combine the first-order conditions for $X$ and for $h$ to get $(1-T)\left(f-X f^{\prime}\right)-(1-\tau) c^{\prime}=$ $w(1-t)$. Similarly, combine the inequalities characterizing $\partial W / \partial h$ and $\partial W / \partial X$, to get $T\left(f-X f^{\prime}\right)-\tau c^{\prime}<t w$. If we multiply the first equation by $t$ and the second equation by $1-t$, then subtract the first equation from the second, we find that

$$
(t-T)\left(f-X f^{\prime}\right)>(t-\tau) c^{\prime}
$$

Since $\tau<t$, we therefore learn in addition that $T<t$. Since $\sigma>0$, we find that $t>T>\tau$ under the optimal policies. In contrast, without transfer pricing, $t=T=\tau$ under the optimal policies.

\subsection{Discussion}

To some degree U.S. tax policy appears to have responded to these pressures. Except for the period 1986-93, corporate tax rates have been below the top personal tax rate, the rate probably most applicable when considering the behavior of potential entrepreneurs. In addition, the U.S. has introduced some special provisions to lower the incentives to make use of transfer pricing. For example, in 1986 the U.S. introduced new rules for allocating interest expenses among the various countries in which a multinational operates. 
Previously a firm could shift income by locating its interest expense where it was most advantageous. The new rules require U.S. multinationals to allocate a fixed fraction of the parent's interest expense to foreign source income, ${ }^{24}$ reducing the deductibility of the parent's interest payments and thereby reducing the incentive for intracorporate borrowing. ${ }^{25}$ A similar allocation procedure is used for $R \& D$ expenses.

A change in enforcement policy now under discussion is to judge the plausibility of a multinational's domestic profits as a whole, rather than the plausibility of each of the prices used in calculating profits. This would be done presumably by comparing a ratio of the firm's profits to sales or capital, to an equivalent ratio for purely domestic firms operating in the same industry. In the limit, the firm would simply be assigned profits for tax purposes equal to the profits to sales ratio observed for domestic firms times the subsidiary's reported sales. As a result, the tax becomes a tax on sales rather than a tax on income, with the rate varying by industry. Transfer pricing would no longer affect a firm's tax liabilities, except to the degree to which it affected reported sales revenue, or reported capital values. In the notation of our model, this policy has a positive $\sigma$ but a zero value of $\tau$, a policy not directly consistent with the results from the model but arguably not a distant approximation.

Note that we have assumed in this model that only inputs are subject to transfer pricing, so that a tax tied to sales revenue is not vulnerable to transfer pricing. It could equally well be the case, however, that outputs are subject to transfer pricing, e.g. intermediate goods could be sent abroad for assembly. Some of our specific results certainly change if we allow for the export of outputs. But the main conclusion should be robust: countries face pressure to keep corporate rates low to discourage transfer pricing, at the expense of distorting individual career choices. ${ }^{26}$

\footnotetext{
24 Usually the allocation fraction is equal to the ratio of foreign to worldwide assets. This allocation rule is itself vulnerable to shifting; for example, firms could reduce the allocation by leasing foreign assets and buying assets used in domestic operations.

25 Gordon and MacKie-Mason (1991) examine the theoretical implications of the new U.S. interest allo cation rule for borrowing location, while Froot and Hines (this volume) and Collins and Shackelford (1992) provide empirical evidence regarding its impact on firm behavior.

26 The policy proposal to base taxes on sales is obviously very vulnerable to transfer pricing on exported outputs.
} 
So far, we have taken the value of $\rho$ as given. What happens as $\rho$ is changed? If $\rho$ is raised, use of transfer pricing drops. For high enough values of $\rho$, multinationals will choose not to set up subsidiaries abroad, eliminating any problems from transfer pricing. The tax systern would then revert to a wage tax supplemented by an equal rate cash-flow corporate tax, given the assumptions of the model. Within the model, there is no efficiency loss from taxing more heavily the pure profits earned by foreign subsidiaries, since transfer pricing aside they earn no pure profits, so this would be the optimal policy.

One way to raise the value of $\rho$ is to force more rapid repatriation of profits from abroad, and in the limit by taxing foreign-source income at accrual. Such a policy may be costly to enforce. Another way would be to decrease the tax on domestic-source capital income, thereby reducing the gain from having funds accumulate abroad free of this domestic tax. In the limit, if there were no domestic tax on capital income, then there would be no gain from the deferral until repatriation of the tax due on foreign-source income. ${ }^{27}$ We can also solve for the optimal values of $a$ vs. $F$. Here, the result is immediate and clear. Holding $a F$ fixed, and thereby holding $p^{*}$ fixed, the government would want to lower $a$ in order to save on resource costs, and increase fines to compensate. Fines can equally well discourage transfer pricing, but involve a redistribution from the firm to the government rather than a loss of real resources. This is simply a replication of the results in Becker (1968).

Imposing large fines on those caught using transfer pricing results in firms facing sizable risks, however, since it is uncertain whether or not use of transfer prices will be detected by the government. Polinsky and Shavell (1979) have argued against such aggressive use of fines because of the risk-bearing costs this policy imposes. But idiosyncratic risk faced by publicly traded firms should impose little or no risk-bearing costs on diversified shareholders. Large fines can well lead to heavy litigation costs, however, and these litigation costs must be traded off with the real costs of greater enforcement efforts. Another problem with high fines is that the government's assessment of the market price may be systematically in error, so that the high potential fines force the firm to make use of distorted prices for tax purposes, thereby distorting its real decisions. Since the government may be in a poor

27 This is equivalent to arguing that the current tax treatment of pensions would not affect the return to labor in a setting with a proportional wage tax and no capital income taxes. 
position to guess the appropriate market price for each of the thousands of specific items transferred within a firm, large fines could well lead to substantial distortions to internal allocation decisions within firms.

Rather than the government expending resources on enforcement, it could instead require firms to expend resources, e.g. to document more carefully the criteria used in setting their transfer prices, to aid the government in its enforcement efforts. Simply shifting resource costs to the firm, however, does not eliminate the loss of real resources. ${ }^{28}$ Note in addition that this approach may be more effective at raising $\beta$ than at raising $a$, yet increases in $\beta$ have ambiguous effects on the firm's net gain from using transfer pricing.

\section{Other Tax Implications of Income Shifting}

The above model helps explain the existence of at least cash-flow corporate taxes in small open economies, and justifies some deviations from a cash-flow tax in order to lessen the amount of transfer pricing that occurs. The mere existence of corporate income taxes is not the only puzzle raised in the recent theoretical analyses of optimal tax policy in an open economy, however. Many detailed aspects of existing taxes have also seemed puzzling. In particular, the past literature argues that residence-based taxes on the return to savings can be appropriate for a small open economy, but that source-based taxes would not be. Yet existing corporate taxes deviate in a variety of ways from a residence-based tax. To begin with, existing taxes apply equally to all firms operating in a country, whereas a residence-based tax would not tax the return earned by foreign-owned firms operating in the country - doing so prevents the country from taking full advantage of the gains from trade in the world capital market. Second, when domestic-owned subsidiaries operating abroad face local taxes, a number of authors (e.g. Hamada (1966)) have argued that these taxes should be treated as a deductible expense, rather than credited against domestic taxes as under U.S. law. The idea is that a tax system should be designed so that the return to the country on domestic vs. foreign investments is equated, and the return to the

28 It is certainly possible that resources expended by firms gathering internal information may improve enforcement more than equivalent resources expended by the government attempting to acquire the same information from a distance. 
country on foreign investments would be measured net of any taxes paid abroad. Third, under a pure residence-based tax domestic-owned subsidiaries operating abroad would be taxed on their income at accrual (so that income from domestic and foreign sources is taxed at the same rate), rather than at repatriation as under existing taxes.

Each of these aspects of existing corporate taxes seem puzzling, if the corporate tax were in fact being designed to tax the return to savings by domestic residents. As argued above, however, another important use of a corporate tax is as a backstop to the tax on the labor income of domestic residents. If this is the sole role for the corporate tax, i.e. if there is no attempt to tax the return to savings by domestic residents, then the above features of the corporate tax can be rationalized easily.

Consider the first puzzle: why do countries impose a source-based tax on foreign firms at the same rate as the residence-based tax on domestic firms? We will treat the case of a host country. We showed above that host countries would have an incentive to impose at least some taxes on foreign subsidiaries located in the country if domestic income shifting is a problem. However, in that model domestic firms are not competitive with multinationals, so all ownership is foreign and we cannot determine the optimal tax rules for domestic firms. If we alter our assumptions to allow some domestic firms to survive in equilibrium (perhaps in a different industry), what would be the appropriate policy? If these firms were not multinationals, they would not be able to shift income across borders. Then by our arguments in section 1, the optimal policy would be a cash-flow tax at rate $t^{*}$, so as to avoid domestic income-shifting. This suggests that domestic-owned and foreignowned firms would face different tax rates, and only employees of foreign-owned firms would engage in domestic income-shifting. But if tax rates differed by ownership, then a new form of income shifting becomes possible: Domestic owners can give away their firms to foreign owners, who receive nothing in return since the firms continue to break even. However, the domestic employees of these firms gain because they can now shift part of their labor income into corporate form, making it subject to the lower corporate tax rate faced by foreign-owned firms. If this nominal transfer of ownership to foreigners is easy enough, then no rate differential between domestic-owned and foreign-owned firms can survive. A similar argument would also achieve this result for foreign and domestic firms that both operate in a home country. 
Next consider the second puzzle: why do countries give credits for foreign taxes paid? To begin with, we have already shown that a government would want to tax income earned abroad, and that the tax on foreign-source income should be designed to limit the incentives for cross-border income shifting. In the model above, this is most directly accomplished by setting $\rho=1$, so that foreign income is taxed at the same rate as domestic income. In fact, international income shifting can take a variety of forms in addition to transfer pricing, increasing the pressure to keep $\rho$ high. For example, if the tax rate on foreign earnings is less than the domestic tax rate on labor income, then domestic entrepreneurs have the incentive to set up subsidiaries abroad that make use of their ideas, rather than at home. (In this case, the subsidiary embodies the ideas of the home-country entrepreneur; in the previous case, it embodied the ideas of the host-country entrepreneur.) Following the logic of section 1, the optimal tax treatment would again involve taxing this foreign source income at the same rate as domestic-source income.

Together these pressures would lead us to expect a subsidiary to be taxed at the maximum of the corporate tax rates prevailing in the host and the home country, to prevent tax avoidance by either domestic or foreign residents. This is precisely what happens under existing crediting schemes (assuming deferral has no effect on the net tax rate). Does crediting introduce other distortions due to the differential tax treatment of foreign and domestic firms operating in the same country? Suppose a domestic entrepreneur considers selling his firm to foreigners. If he keeps the firm himself, he faces the domestic tax rate, but if he sells it to foreigners the firm would face the maximum of the domestic and the foreign rates, which would seem to discourage such a sale even though there might be good economic grounds for it. The foreign firm can avoid this surtax, however, simply by making royalty or wage payments to the original entrepreneur equal to the profits earned from his ideas. The return to the entrepreneur's ideas would still be taxed at the labor income tax rate. Net of these royalty/wage payments, the firm would break even, so that any cash-flow surtax on the firm would collect no revenue and be nondistorting. ${ }^{29}$ Therefore,

29 If the foreign corporate tax is distorting, then the sale can increase tax payments. However, if the foreign tax applies uniformly to firms owned by foreign residents, regardless of where these firms are located, then it simply reduces the return to labor in the foreign countries rather than affecting the attractiveness of acquiring such a firm, leaving the above results unchanged. 
existing crediting schemes can readily be rationalized. ${ }^{30}$

The third puzzle we discuss is why countries tax foreign-source income upon repatriation rather than when it accrues. In fact, the deferral of tax on foreign-source income creates no problems as long as the after-local-tax rate of return earned abroad equals the firm's discount rate. ${ }^{31}$ If the return earned abroad were lower, then the domestic owner could simply repatriate earnings as they accrue. Deferral is only a problem if the rate of return earned on funds kept abroad exceeds that available at home. If the domestic government does not tax the return to savings, then capital mobility implies this cannot occur. Deferral remains a puzzle, however, to the extent to which there is a domestic tax on the return to savings, unless the costs of enforcing a tax at accrual are too high.

While we have provided a rationale for a variety of aspects of existing corporate income taxes, some other puzzles remain. For one, we have not addressed the question raised in the prior literature concerning why existing corporate taxes include the return to capital in the tax base. ${ }^{32}$ In addition, while we have argued that countries have an incentive to tax foreign source income at the same effective rate as domestic-source income, some countries (e.g. France and the Netherlands) exempt foreign-source income from tax. This also seems puzzling, unless their domestic tax rates are low enough that residents would not gain by shifting income abroad. An intermediate position is taken by Norway, which exempts foreign-source income earned in countries with tax rates at least two-thirds as high as Norway's rate, while taxing income from low-tax countries.

Several further complications could be added to the model, changing the results. For example, given the set-up of the model, the optimal tax scheme ignoring transfer pricing would impose equal tax rates on employees and entrepreneurs, in order to avoid distorting career choices. But a major activity of entrepreneurs is to develop new ideas for profitable

30 This theory rationalizes the use of credits, but does not preclude the use of deductions. If taxes paid abroad were allowed as a deduction rather than credited against domestic tax liabilities, as recommended in Hamada (1966), the tax rate on foreign-source income would be yet higher. It would certainly be high enough to prevent income shifting, yet without income shifting it would still apply to a zero tax base so impose no distortions.

31 See footnote 13 , above.

32 While, the above model could rationalize limiting the deductions for capital purchases if physical capital inputs were particularly subject to transfer pricing, this explanation does not seem very plausible. 
business activities. The return earned by entrepreneurs on these new ideas can differ from the social return to the ideas for a variety of reasons, justifying a differential tax treatment to correct for these distorted incentives. For example, others can learn an entrepreneur's ideas from observation and set up competing firms using the same ideas, diluting the profits of the original entrepreneur. ${ }^{33}$ In addition, the original entrepreneur can use his new information to profit from trading on the securities market. As argued by Hirshleifer (1971), the resulting profits from trade can well exceed the social return to the idea. If returns to the entrepreneur's ideas result from acquired monopoly rents, e.g., from successful rent-seeking behavior, then the social return to the effort will again be less than the private return. Therefore, a variety of questions can be raised about the appropriate relative tax rates on employees vs. entrepreneurs.

One response to transfer pricing by U.S. states is to shift from separate accounting to formula apportionment. Under separate accounting, transfer prices are needed for all goods and services traded across state lines, raising severe enforcement problems. In contrast, under formula apportionment, national rather than state profits are calculated. These national profits are then apportioned among the various states based on the fraction of the firm's capital, payroll, and sales located in each state. This approach effectively eliminates pressures from transfer pricing among domestic operations of firms, at least as long as the factors in the formula are not themselves subject to transfer pricing. Would this approach also make sense for taxation at a world level? Not if income shifting is the primary consideration justifying the presence of a corporate income tax. To prevent income shifting, a country would want an entrepreneur to face the same tax rate on his corporate income as he would have faced instead on his personal income. But under formula apportionment, the effective tax rate faced by an entrepreneur would be a weighted average of the tax rates prevailing in all the jurisdictions in which he does business. The entrepreneur therefore has the incentive to invest in low tax jurisdictions, thereby raising the return to being an entrepreneur.

33 Patents provide some limited protection for certain types of ideas, but many profitable ideas are not patentable. 


\section{Conclusions}

Several recent papers, such as Gordon (1986) and Razin and Sadka (1901), show that standard theoretical models forecast that a small open economy will not impose sourcebased taxes on capital income. Unless residence-based capital-income taxes can in practice include foreign-source as well as domestic-source income, which in practice is unlikely given the difficulties a government faces in monitoring foreign-source income, then as argued by Razin and Sadka (1991) residence-based taxes would not be feasible. Optimal taxes simply consist of taxes on immobile domestic factors, presumably labor and land. But this theoretical forecast stands in stark contrast to the observed tax law in essentially all developed countries, where corporate taxes not only exist but where corporate rates are roughly comparable to the top personal tax rates.

In this paper, we argue that many aspects of the existing corporate tax law would seem quite sensible if the primary role of the corporate tax is to discourage income shifting between the personal and the corporate tax bases, or between domestic and foreign subsidiaries. Unless corporate tax rates are roughly comparable to personal tax rates, business owners would be able to avoid taxes by retaining earnings within their firm, and later selling shares in the firm, so that the earnings are taxed at capital gains rates rather than at personal rates. Unless foreign-owned firms operating in the country are subject to domestic taxes at the same rate, then a domestic business owner would be able to avoid taxes on the returns to his ideas by selling his firm to foreign-owners. Similarly, a country would need to tax the income of domestic-owned subsidiaries operating abroad, to prevent entrepreneurs from facing a tax incentive to make use of their ideas abroad rather than in the home country.

If the tax rate on domestic-owned subsidiaries abroad were less than the domestic corporate tax rate, then an additional distortion would be created because multinationals can avoid domestic taxes by shifting their profits abroad through transfer prices even if the firms embodying their profitable ideas remain at home. While taxing foreign-source income at the same rate as domestic-source income eliminates this pressure, a secondbest response is to lower the domestic tax on elements of the income statement that are 
most subject to transfer pricing. For example, the U.S. has reduced the effective tax rate applying to interest deductions of multinationals through its section 482 rules.

Viewing the corporate tax as primarily a backstop to the personal tax on labor income, rather than as primarily a tax on capital income, requires an important change in focus from that of the recent academic literature. Given the ease with which existing tax policy can be rationalized based on this role for the corporate tax, such a change in focus appears warranted. How great are the pressures from income shifting between the personal and the corporate tax bases? We have presented some evidence in Gordon and MacKie-Mason (1994) and MacKie-Mason and Gordon (1992) on the degree to which firms change between corporate and noncorporate status in response to tax incentives. There has been virtually no attempt to date in the tax literature, however, to measure the degree to which individuals shift their form of pay in response to tax differences. Since our model suggests that this form of income-shifting appears to be a major consideration in the design of existing tax structures, measuring the degree to which such income shifting occurs in response to tax differences is an important topic for future research. 


\section{APPENDIX}

Proof that $\partial W / \partial h<0$ when $w_{n}$ is held constant.

In the model with both domestic and cross-border income-shifting, consider the effects in the home country of raising $\tau$ and in addition raising $T$ by enough to keep firms' choice for $X$ unchanged, given $p^{*}$. Assume in addition that $t$ is simultaneously cut by enough so as to keep $w_{n}$ unchanged. ${ }^{34}$ Under the optimal tax policy, the resulting marginal change in welfare should be zero. The resulting change in welfare equals

$$
\frac{\partial W}{\partial p^{*}}\left(\frac{\partial p^{*}}{\partial \tau}+\frac{\partial p^{*}}{\partial T} \frac{\partial T}{\partial \tau}\right)+\frac{\partial W}{\partial h}\left(\frac{\partial h}{\partial \tau}+\frac{\partial h}{\partial T} \frac{\partial T}{\partial \tau}+\frac{\partial h}{\partial t} \frac{\partial t}{\partial \tau}\right)=0
$$

It is straight-forward to demonstrate that the combined increases in $\tau$ and $T$ cause $p^{*}$ to rise, and that this rise in $p^{*}$ lowers welfare. Therefore, the second term in equation (A.1) must be positive. But the increase in business taxes and the drop in labor taxes will cause $h$ to fall, implying that $\partial W / \partial h$ must be negative, when evaluated at the optimal policies.

\section{Proof that $\partial W / \partial X>0$ when $w_{n}$ is held constant}

In the model with both domestic and cross-border income shifting, consider the effects of raising $\sigma$, while cutting $t$ so as to leave $w_{n}$ unchanged. The first-order condition is

$$
\frac{\partial W}{\partial h}\left(\frac{\partial h}{\partial \sigma}+\frac{\partial h}{\partial t} \frac{\partial t}{\partial \sigma}\right)+\frac{\partial W}{\partial p^{*}} \frac{\partial p^{*}}{\partial \sigma}+\frac{\partial W}{\partial X} \frac{\partial X}{\partial \sigma}=0 .
$$

This tax policy raises corporate taxes and cuts personal taxes. As a result, $h$ will fall, implying that the first term in equation (A.2) is positive. In addition, raising the surtax on repatriated profits by raising $\sigma$ makes transfer pricing relatively less attractive. Thus $p^{*}$ decreases, implying that the second term is also positive. Therefore, the third term must be negative. But the increase in the surtax on revenues leads to a reduction in $X$, implying that $\partial W / \partial X>0$ under the optimal policies.

34 That the required change in $t$ is negative is straight-forward but tedious to demonstrate. 


\section{REFERENCES}

Auerbach, Alan (1983) "Taxation, Corporate Financial Policy, and the Cost of Capital," Journal of Economic Literature, 21, 905-40.

Becker, Gary S. (1968) "Crime and Punishment: An Economic Approach," Journal of Political Economy, 76, 169-217.

Collins, Julie H. and Douglas A. Shackelford (1992) "Foreign Tax Credit Limitations and Preferred Stock Issuances," Working Paper, University of North Carolina Business School.

Feldstein, Martin S. and Charles Horioka (1980) "Domestic Savings and International Capital Flows," The Economic Journal, 90, 314-29.

Froot, K. and J. Hines (1994) "Multinational Firms and the Changing Cost of Debt Finance, ${ }^{n}$ This volume.

Gordon, Roger H. (1992) "Can Capital Income Taxes Survive in Open Economies?," Journal of Finance, 47, 1159-80. (1986) "Taxation of Investment and Savings in a World Economy," American Economic Review, 76, 1086-1102.

Gordon, Roger H. and A. Lans Bovenberg (1993) "Why is Capital so Immobile Internationally: Possible Explanations and Implications for Capital Income Taxation, " manuscript, University of Michigan.

Gordon, Roger H. and Jeffrey K. MacKie-Mason (1994) "Tax Distortions to the Choice of Organizational Form," Forthcoming in Journal of Public Economics. Earlier version released as NBER Working Paper No. 4227.

Gordon, Roger H. and Jeffrey K. MacKie-Mason (1991) "Effects of the Tax Reform Act of 1986 on Corporate Financial Policy and Organizational Form," in Do Taxes Matter?: The Impact of the Tax Reform Act of 1986, ed. Joel Slemrod. Cambridge, MA: MIT Press. 
Gordon, Roger H. and Joel Slemrod (1988) "Do We Collect Any Revenue from Taxing Capital Income?," Tax Policy and the Economy, 2, 89-130.

Gravelle, J. G. and L. J. Kotlikoff (1989) "The Incidence and Efficiency Costs of Corporate Taxation When Corporate and Noncorporate Firms Produce the Same Good, Journal of Political Economy, 97, 749-81.

Grubert, Harry and Jack Mutti (1987) "The Impact of the Tax Reform Act of 1986 on Trade and Capital Flows, ${ }^{n}$ in Compendium of Tax Research 1987. Washington, D.C.: U.S. Treasury Department.

Grubert, Harry and Joel Slemrod (1993) "The Effects of Taxes on Investment and Income Shifting to Puerto Rico," mimeo, University of Michigan.

Hamada, Koichi (1966) "Strategic Aspects of Taxation on Foreign Investment Income," Quarterly Journal of Economics, 80, 361-75.

Harris, David, Randall Morck, Joel Slemrod and Bernard Yeung (1993) "Income Shifting in U.S. Multinational Corporations, " in Studies in International Taxation, ed. Alberto Giovannini, R. Glenn Hubbard, and Joel Slemrod. Chicago: University of Chicago Press.

Hines, James, Jr. and R. Glenn Hubbard (1990) "Coming Home to America: Dividend Repatriations by U.S. Multinationals, ${ }^{n}$ in Taxation in a Global Economy, ed. Assaf Razin and Joel Slemrod. Chicago: University of Chicago Press.

Hines, James R., Jr. and Eric M. Rice (1990) "Fiscal Paradise: Foreign Tax Havens and American Business," NBER Working Paper No. 3477.

Hirshleifer, Jack (1971) "The Private and Social Value of Information and the Reward to Inventive Activity," American Economic Review, 61, 561-74.

MacKie-Mason, Jeffrey K. and Roger H. Gordon (1993) "How Much Do Taxes Discourage Incorporation?," Previous version released as NBER Working Paper No. 3781.

Musgrave, Richard (1959) The Theory of Public Finance. New York: McGraw-Hill. 
Polinsky, A. Mitchell and Steven Shavell (1979) "The Optimal Tradeoff between the Probability and Magnitude of Fines," American Economic Review, 69, 880-91.

Razin, Assaf and Efraim Sadka (1991) "International Tax Competition and Gains from Tax Harmonization," Economics Letters, 37, 69-76.

Shoven, John (1991) "Using the Corporate Cash Flow Tax to Integrate Corporate and Personal Taxes," Proceedings of the 83rd Annual Conference of the National Tax Association, 83, 19-26. 
</ref_section> 